\title{
PENINGKATAN KEMAMPUAN PEMAHAMAN DAN ANALISIS MASALAH PADA PSIKOLOGI FAAL MELALUI PEMBELAJARAN BERBASIS AKTIVITAS
}

\author{
Ambar Sulianti \\ Fakultas Psikologi UIN Sunan Gunung Djati Bandung, Jl. A.H Nasution No. 105 Bandung \\ email: ambarleeanty@gmail.com
}

\begin{abstract}
Abstrak
Penelitian ini bertujuan untuk mengetahui pengaruh penerapan metode pembelajaran berbasis aktivitas terhadap peningkatan kemampuan pemahaman konsep dan analisis masalah dalam mata kuliah Psikologi Faal di Fakultas Psikologi UIN SGD Bandung. Penelitian ini dilakukan pada 68 mahasiswa semester satu yang dibagi menjadi kelompok kontrol dan perlakuan. 34 subjek pada kelompok kontrol mendapatkan metode pembelajaran ceramah dan multimedia non animasi sedangkan 34 subjek pada kelompok perlakuan mendapatkan metode pembelajaran berbasis aktivitas. Analisis data dilakukan melalui Uji T tidak berpasangan. Hasil penelitian menunjukkan bahwa metode pembelajaran berbasis aktivitas dapat meningkatkan kemampuan pemahaman konsep dan analisis masalah.
\end{abstract}

Kata Kunci: metode, aktivitas, faal

\section{Abstract}

This research aims to know the effect of learning based activity toward understanding of concepts and problem analysis in psyco-pshysiology class of pshycology faculty, Islamic state university. Participants are 68 first year students which are divided into control group and treatment group. 34 students of control group have lecturing and multimedia non animated method while other 34 studends of treatment group have activity based learning method. Data were analyzed using Independent T-Test. Result shows that activity based learning method improve the understanding of concepts and problem analysis ability.

Keywords: method, activity, pshyco-physiology

\section{PENDAHULUAN}

Mahasiswa Fakultas Psikologi dituntut tidak hanya untuk memahami berbagai konsep teori mengenai Psikologi dan mempraktikan Psikologi, tetapi juga memahami konsep-konsep kesehatan yang berhubungan dengan Psikologi serta menganalisis dan merumuskan pemecahan masalah-masalah kesehatan yang ber- hubungan dengan Psikologi. Salah satu matakuliah yang diberikan mahasiswa Fakultas Psikologi yang berhubungan dengan kesehatan adalah matakuliah Psikologi Faal.

Matakuliah Psikologi Faal, merupakan matakuliah penting yang merupakan bagian dari ilmu dasar yang menjadi pendukung dalam kehidupan keseharian dan dalam profesi mahasiswa tersebut. 
Matakuliah ini diberikan pada mahasiswa tahun pertama, di mana pada semester awal tersebut mahasiswa berada dalam tahap adaptasi transisi dari siswa SMU/Aliyah menjadi mahasiswa. Matakuliah Psikologi Faal ini memberikan pengetahuan tentang Istilan-Istilah dalam Psikologi Faal, Sistem Indera dan Hubungannya dengan perilaku, Sistem Kardiovaskuler dan Hubungannya dengan perilaku, Sistem Hormon dan Hubungannya dengan perilaku, Perkembangan Psikologi Faal dan Proses Patogenik Penyebab Penyakit, Konsep Biologi Seluler, Biologi Molekuler, dan Teori Evolusi dalam Pandangan Islam.

Meskipun matakuliah Psikologi Faal penting bagi mahasiswa Fakultas Psikologi, dari hasil evaluasi belajar menunjukkan bahwa mahasiswa jurusan Fakultas Psikologi belum memperlihatkan hasil belajar yang menunjukkan tingkat pemahaman yang diharapkan sesuai dengan kurikulum. Hasil pengamatan selama 2 tahun terhadap nilai matakuliah Psikologi Faal mahasiswa angkatan 2009-2010, lebih dari $50 \%$ nilai mahasiwa berada pada kisaran huruf mutu $C$ dan D . Hasil belajar yang demikian tentu sangat memprihatinkan dalam menentukan kualitas lulusan dan profesionalisme kerja mereka nantinya.

Berdasarkan pengisian angket yang dibagikan kepada mahasiswa, hasil belajar yang rendah ini disebabkan oleh beberapa faktor. Mahasiswa memandang matakuliah Psikologi Faal merupakan matakuliah yang sulit karena sebagian mahasiswa tidak memperoleh pelajaran Biologi sewaktu SMU/Aliyah. Mahasiswa mengalami kesulitan untuk dapat memahami berbagai konsep teori psikologi faal dan menganalisis masalah-masalah yang berhubungan dengan perilaku dengan metode belajar ceramah sehingga menimbulkan rasa jenuh dalam belajar. Kegiatan belajar dalam perkuliahan dirasakan lebih sebagai beban daripada upaya aktif untuk memperdalam ilmu.
Mahasiswa tidak menemukan kesadaran untuk belajar ataupun mengerjakan tugastugas yang diberikan.

Bertolak dari permasalahan di atas, dosen perlu memberikan respon positif secara konkret dan objektif yaitu berupa upaya untuk membangkitkan minat belajar dan partisipasi mahasiswa, baik dalam bentuk kontributif maupun inisiatif. Bentuk partisipasi kontributif dan inisiatif ini akan mampu membentuk mahasiswa untuk selalu aktif dan kreatif sehingga mereka sadar ilmu itu merupakan suatu kebutuhan yang mereka perlukan dan ilmu itu hanya bisa diperoleh melalui usaha. Masalah utama dalam proses pembelajaran ini adalah "Bagaimana dosen mengajarkan bahan-bahan kajian dengan cara menarik menggunakan fasilitas yang tersedia sehingga mahasiswa memperoleh pemahaman dan tidak merasa bosan dalam belajar?"

Berdasarkan pandangan tersebut di atas, maka dirasa perlu oleh dosen mengubah metode pembelajaran yang selama ini dilakukan dengan metode yang lebih inovatif dengan menggunakan fasilitas yang tersedia. Metode yang dicoba untuk diterapkan adalah pembelajaran berbasis aktivitas. Terdapat beberapa kegiatan yang dilakukan dalam metode pembelajaran berbasis aktivitas yaitu kegiatan visual, kegiatan mendengarkan, kegiatan menulis, kegiatan menggambar, kegiatan metrik, kegiatan mental, dan kegiatan emosional (Dierich, 1999).

Berdasarkan latar belakang masalah di atas, permasalahan yang ada dapat dirumuskan sebagai berikut:

1. Apakah metode pembelajaran berbasis aktivitas meningkatkan pemahaman matakuliah Psikologi Faal mahasiswa Fakultas Psikologi UIN SGD?

2. Apakah metode pembelajaran berbasis aktivitas meningkatkan kemampuan analisis masalah yang berhubungan dengan perilaku pada matakuliah Psikologi Faal mahasiswa Fakultas Psikologi UIN SGD? 


\section{Hakikat Belajar Mengajar}

Proses belajar mengajar adalah suatu rangkaian peristiwa yang sangat kompleks. Dalam hal ini banyak variabel yang saling berhubungan, sehingga kita tidak dapat menentukan bagaimana variabel-variabel itu berinteraksi satu sama lain. Belajar pada hakikatnya merupakan suatu proses perubahan yang terjadi dalam hal keterampilan, kebiasaan, sikap, pengertian, pengetahuan atau apresiasi. (Bahri,1997; Mudyaharyo,1985). Pendapat lain mengemukakan bahwa belajar tidak lain merupakan proses yang memungkinkan berbagai potensi yang ada dalam diri siswa dan dapat berinteraksi secara aktif dengan fakta-fakta serta konsep-konsep yang muncul dalam kelas dengan lingkungan belajar sebagai suatu kesatuan (Kusmana, 2001).

Mengajar pada hakikatnya merupakan suatu proses pengaturan dan pengorganisasian lingkungan yang ada di sekitar siswa guna menumbuhkan dan mendorong untuk belajar. Pada tahap berikutnya mengajar adalah proses memberikan bimbingan atau bantuan kepada siswa dalam melakukan proses belajar (Sudjana, 2000). Dengan demikian mengajar merupakan aktivitas fasilitasi dan pemberi arah bagi aktifitas belajar siswa. Oleh karena itu dalam proses belajar mengajar guru harus dapat berperan sebagai fasilitator belajar bagi siswa. (Costa,1985; Joyce at all,2000; Munandar,2002).

Belajar mengajar menurut Nana Sudjana (2000) merupakan proses penkoordinasian komponen tujuan, bahan, metode dan alat serta penilaian agar satu sama lain saling berhubungan dan saling berpengaruh. Sehinga menimbulkan minat belajar pada siswa seoptimal mungkin menuju tercapainya peubhan tingkah laku siswa sesuai dengan tujuan yang telah ditetapkan.

Burton dalam Abin Syamsuddin (1986) menyatakan bahwa siswa dalam kesulitan belajar bila siswa yang bersangkutan menunjukkan kegagalan tertentu dalam mencapai tujuan belajarnya. Dan Burton mendefinisikan kegagalan sebagai beikut :

Apabila dalam waktu tertentu yang telah ditetapkan, tidak mencapai ukuran tingkat kebehasilan atau tingkat penguasaan minimal dalam pelajaran tertentu yang telah ditetapkan oleh orang dewasa atau guru.

Apabila yang bersangkutan tidak dapat mengerjakan atau mencapai prestasi yang semestinya.

Apabila yang bersangkutan tidak dapat mewujudkan tugas-tugas perkembangannya.

Dengan demikian dapat disimpulkan bahwa seorang siswa dikatakan mengalami kesuitan belajar apabila yang bersangkutan tidak berhasil mencapai taraf kualifikasi hasil belajar tertentu berdasarkan kriteria yang telah ditetapkan dalam batas-batas waktu yang telah ditentukan.

Faktor-faktor penyebab kesulitan belajar terbagi menjadi dua faktor utama, yaitu: faktor intern dan ekstern. Faktor intern adalah faktor yang terdapat dalam diri siswa sendiri, sedangkan faktor ekstern adalah faktor yang terdapat di luar diri siswa. Yang termasuk faktor intern adalah kelemahan mental, gangguan emosional, kurangnya minat belajar, kurang motivasi dan sebagainya. Yang termasuk faktor ekstern adalah situasi proses belajar yang tidak menunjang, lingkungan sekolah, situasi tempat dan keluarga siswa belajar, serta situasi lingkungan sosial.

\section{Aktivitas Belajar}

Aktivitas merupakan prinsip atau asas yang sangat penting didalam interaksi belajar-mengajar. Dalam aktivitas belajar ada beberapa prinsip yang berorientasi pada pandangan ilmu jiwa, yakni menurut pandangan ilmu jiwa lama dan ilmu jiwa modern. Menurut pandangan ilmu jiwa lama aktivitas didominasi oleh guru sedang menurut padangan ilmu jiwa modern, aktivitas didominasi oleh siswa. 
Aktivitas belajar merupakan hal yang sangat penting bagi siswa, karena memberikan kesempatan kepada siswa untuk bersentuhan dengan obyek yang sedang dipelajari seluas mungkin, karena dengan demikian proses konstruksi pengetahuan yang terjadi akan lebih baik. Aktivitas Belajar diperlukan aktivitas, sebab pada prinsipnya belajar adalah berbuat mengubah tingkah laku, jadi melakukan kegiatan. Tidak ada belajar kalau tidak ada aktivitas. Dengan demikian, aktivitas belajar adalah keterlibatan siswa dalam bentuk sikap, pikiran, perhatian dalam kegiatan belajar guna menunjang keberhasilan proses belajar mengajar dan memperoleh manfaat dari kegiatan tersebut.

Salah satu cara untuk megatasi kesulitan belajar adalah dengan meningkatkan kualitas proses belajar mengajar (Hopkins, 1991), upaya peningkatan kualitas pembelajaran dengan penelitian tindakan kelas. Penelitian ini untuk memperbaiki cara mengajar dan menguji asumsi-asumsi teori dan praktek pembelajaran.

Pengajaran dengan berbasis aktivitas berdasarkan klasifikasi dari Paul D. Dierich (Sardiman, 2011: 101) membagi kegiatan dalam 8 kelompok:

a. Kegiatan visual

Membaca, melihat gambar, mengamati eksperimen, demonstrassi, dan mengamati orang bekerja atau bermain.

b. Kegiatan-kegiatan lisan

Mengemukakan suatu fakta atau prinsip, menghubungkan suatu kejadian, mengajukan pertanyaan, memberi saran, mengemukakan pendapat, wawancara,diskusi dan interupsi.

b. Kegiatan mendengarkan

Mendengarkan penyajian bahan, percakapan atau diskusi kelompok, suatu permainan, radio.

c. Kegiatan menulis

Menulis cerita, laporan, memeriksa karangan, membuat rangkuman, mengerjakan tes, dan mengisi angket. d. Kegiatan menggambar

Menggambar, membuat grafik, chart, diagram,peta dan peta.

e. Kegiatan metrik

Melakukan percobaan, memilih alat-alat, melaksanakan pameran, membuat metode, menyelenggarakan permainan, menari dan berkebun.

f. Kegiatan mental

Merenungkan, mengingat, memecahkan masalah, menganalisis factor-faktor, melihat hubungan dan membuat keputusan.

g. Kegiatan emosional

Minat, membedakan, berani, tenang, dan lain-lain.

Kegiatan-kegiatan ini terdapat dalam setiap jenis kegiatan dan overlap satu sama lain.

\section{Prestasi Belajar}

Belajar merupakan kegiatan yang berproses dan merupakan unsur yang sangat fundamental dalam setiap penyelenggaraan jenis dan jenjang pendidikan. Berarti bahwa berhasil atau gagalnya pencapaian tujuan pendidikan itu sangat bergantung pada proses belajar yang dialami siswa, baik ketika ia berada di sekolah maupun di lingkungan rumah atau keluarga sendiri.

Winkel (2005) mengatakan bahwa "prestasi belajar adalah suatu bukti keberhasilan belajar atau kemampuan seseorang siswa dalam melakukan kegiatan belajarnya sesuai dengan bobot yang dicapainya". Prestasi belajar dapat diukur dengan penilaian. Penilaian atau evaluasi pada dasarnya adalah memberikan pertimbangan atau harga atau nilai berdasarkan kriteria tertentu Nana Sudjana (2010) mengemukakan bahwa prestasi belajar adalah hasil belajar yang telah dicapai melalui pengukuran dan penilaian terhadap penguasaan pengetahuan dan keterampilan yang diperoleh siswa melalui proses belajar mengajar yang dinyatakan dalam simbul, angka, huruf atau kode. 
Prestasi merupakan faktor penting untuk menentukan tingkat pengetahuan siswa. Prestasi yang dimaksud dalam penelitian ini adalah nilai akhir penyajian materi mata diklat PLC yang diberikan dengan memberikan latihan untuk dikerjakan di kelas dengan tujuan untuk mengetahui tingkat prestasi belajar siswa dengan cara memberikan soal-soal pada siswa.

Untuk menentukan prestasi belajar dapat diukur dengan penilaian. Dengan demikian penilaian adalah proses memberikan atau menentukan nilai kepada objek tertentu berdasarkan suatu kriteria tertentu. Benyamin Bloom dalam Nana Sudjana (2010) mengemukakan prestasi belajar yang dicapai oleh siswa dapat dikelompokkan menjadi tiga ranah/aspek, yaitu:

1. Ranah kognitif berkenaan dengan hasil belajar intelektual yang terdiri dari enam aspek,yakni pengetahuan atau ingatan, pemahaman, aplikasi, analisis, sintesis dan evaluasi.

2. Ranah afektif berkenaan dengan sikap yang terdiri dari lima aspek, yakni penerimaan, jawaban atau reaksi, penilaian, organisasi dan internalisasi.

3. Ranah Psikomotoris berkenaan dengan hasil belajar keterampilan dan kemampuan bertindak. Ada enam aspek ranah psikomotoris, yaitu gerakan refleks, keterampilan gerakan dasar, kemampuan perseptual, keharmionisan atau ketepatan, gerakan keterampilan kompleks dan gerakan ekspresif.

Berdasarkan latar belakang dan rumusan masalah di atas, disusun hipotesis yang akan diuji kebenarannya sebagai berikut:

1. Metode pembelajaran berbasis aktivitas meningkatkan pemahaman matakuliah Psikologi Faal mahasiswa Fakultas Psikologi UIN SGD.

2. Metode pembelajaran berbasis aktivitas meningkatkan kemampuan analisis masalah yang berhubungan dengan perilaku pada matakuliah Psikologi Faal mahasiswa Fakultas Psikologi UIN SGD?

\section{METODOLOGI PENELITIAN}

Desain penelitian ini merupakan penelitian eksperimen dengan rancangan test sebelum dan sesudah dengan kontrol (pre-post test with controle design). Pada penelitian ini dianalisis secara kuantitatif perbedaan nilai tes tertulis pada mahasiswa kelompok kontrol dan kelompok perlakuan. Kelompok perlakuan diberikan metode pembelajaran berbasis aktivitas sedangkan kelompok kontrol diberikan metode pengajaran menggunakan multi media tanpa animasi. Pada akhir penelitian, kedua kelompok diberikan tes tertulis dengan soal yang sama.

Data yang diolah pada penelitian ini ialah data dari subjek penelitian yang mengikuti penelitian sampai akhir dan mengikuti ujian/tes tertulis. Subjek penelitian ini adalah mahasiswa Fakultas Psikologi UIN SGD Bandung tahun ajaran 2012/2013, Jumlah mahasiswa Fakultas Psikologi UIN SGD yang menjadi subjek penelitian ini adalah 68 orang yang terbagi dalam 2 kelompok.

Analisis data menggunakan metode statistik kuantitatif berupa uji perbedaan nilai kelompok kontrol dan kelompok perlakuan menggunakan $\mathrm{Uji} T$ tidak berpasangan untuk data berdistribusi normal. Penelitian ini dilakukan dalam 50 hari dan dilaksanakan di ruang kuliah Fakultas Psikologi UIN SGD Bandung.

\section{HASIL PENELTIAN DAN PEM- BAHASAN}

Data yang diolah pada penelitian ini ialah data dari subjek penelitian yang mengikuti penelitian sampai akhir dan mengikuti tes tertulis pada akhir penelitian. Setelah dilakukan pemberian perlakuan selama 3 pertemuan tatap muka, diperoleh data perbedaan nilai tes tertulis untuk kategori kemampuan pemahaman 
kelompok kontrol dan perlakuan disajikan pada Tabel 4.2. berikut

Tabel 4.2.

Deskriptif Nilai Tes Tertulis Kategori Pemahaman Kelompok Perlakuan dan Kontrol

\begin{tabular}{llllll}
\hline Kelompok & N & Minimum & Maximum & Mean & $\begin{array}{l}\text { Standar } \\
\text { Deviasi }\end{array}$ \\
\hline Perlakuan & 34 & 66 & 100 & 89,56 & 9,67 \\
\hline Kontrol & 34 & 20 & 90 & 68,32 & 14,86 \\
\hline
\end{tabular}

Berdasarkan tabel di atas tampak rerata nilai tes pemahaman psikologi faal pada kelompok perlakuan lebih tinggi yaitu $89,56 \quad( \pm 9,67)$ dibandingkan kelompok kontrol yaitu $68,32( \pm 14,86)$.

Tabel 4.3

Uji Kemaknaan Nilai Tes Pemahaman Kelompok Perlakuan dan Kontrol

\begin{tabular}{llll}
\hline Parameter & n & Rerata \pm SD & p \\
& & & \\
\hline Kelompok Kontrol & 34 & $89,56 \pm 9,67$ & 0,00 \\
Kelompok Perlakuan & 34 & $68,32 \pm 14,86$ & \\
\hline
\end{tabular}

Tabel tersebut menunjukkan terdapat perbedaan bermakna antara nilai tes pemahaman kelompok perlakuan dan kelompok kontrol $(\mathrm{p}=0.00)$.

Data hasil perbedaan nilai tes tertulis untuk kategori kemampuan analisis kasus kelompok kontrol dan perlakuan disajikan pada Tabel 4.4. berikut

Tabel 4.4.

Deskriptif Nilai Tes Tertulis Kategori Analisis Kasus Kelompok Perlakuan dan Kontrol

\begin{tabular}{llllll}
\hline Kelompok & N & Minimum & Maximum & Mean & $\begin{array}{l}\text { Standar } \\
\text { Deviasi }\end{array}$ \\
\hline Perlakuan & 34 & 68 & 99 & 88,00 & 8,32 \\
\hline Kontrol & 34 & 20 & 88 & 64,56 & 14,32 \\
\hline
\end{tabular}

Berdasarkan tabel di atas tampak rerata nilai tes pemahaman psikologi faal pada kelompok perlakuan lebih tinggi yaitu $88( \pm 8,32)$ dibandingkan kelompok kontrol yaitu 64,56 $( \pm 14,32)$.

Untuk melihat kemaknaan perbedaan nilai analisis kasus antara kelompok kontrol dan perlakuan dilakuan uji T tidak berpasangan. Hasil dari analisis uji $\mathrm{T}$ tidak berpasangan dapat dilihat pada tabel 4.5 berikut.

Tabel 4.5.

Uji Kemaknaan Nilai Tes Analisis Kasus Kelompok Perlakuan dan Kontrol

\begin{tabular}{llll}
\hline Parameter & n & Rerata \pm SD & p \\
\hline Kelompok Kontrol & 34 & $88 \pm 8,32$ & 0,00 \\
Kelompok Perlakuan & 34 & $-64,56 \pm 14,32$ & \\
\hline
\end{tabular}

Tabel tersebut menunjukkan terdapat perbedaan bermakna antara nilai tes pemahaman kelompok perlakuan dan kelompok kontrol $(\mathrm{p}=0.00)$.

Banyak variabel yang saling berinteraksi memperngaruhi proses belajar mengajar. Dalam metode pembelajaran berbasis aktivitas, penekanan metode pembelajaran adalah aktivitas siswa.

Menurut teori belajar konektivisme dari Thorndike yang termasuk ke dalam teori behaviorisme, belajar dapat terjadi dengan dibentuknya hubungan yang kuat antara stimulus dan respons. Agar tercapai hubungan antara stimulus dan respons, perlu adanya kemampuan untuk memilih respons yang tepat serta melalui percobaan-percobaan (trials) dan kegagalankegagalan (error) terlebih dahulu. Dalam sistem metode pembelajaran berbasis aktivitas, mahasiswa diberi stimulus untuk melakukan berbagai percobaan dalam bentuk 3 dimensi membuat alat peraga psikologi faal yatiu salah satu indera kita yang dapat dilihat dan diraba. Mahasiswa kemudian diminta menjelaskan dan melakukan pengulangan dalam menjelaskan. Mahasiswa juga diberi pengertian apa manfaat dari mempelajari sistem indera dan diberi motivasi untuk menerapkannya dalam bentuk pembuatan alat peraga tiga dimensi. Hal ini mendukung tahapan proses pembelajaran yang dikemukakan oleh Robert Gagne bahwa tahapan proses pembelajaran meliputi delapan fase yaitu, (1) motivasi; (2) pemahaman; (3) pemerolehan; (4) penyimpanan; (5) ingatan kembali; (6) 
generalisasi; (7) perlakuan dan (8) umpan balik.

Untuk kegiatan visual mahasiswa diajak melihat gambar, mengamati alat peraga yang telah dibuatnya. Mahasiswa diminta berdiskusi dalam kelompok untuk saling mendengarkan dan bertukar pikiran. Selanjutnya mahasiswa diminta membuat grafik/ peta/ diagram untuk menilai sejauh mana mereka memahami dan dapat meringkas dalam sebuah grafik/ peta/ diagram. Mahasiswa juga dituntut untuk menulis rangkuman tentang fungsi (faal) dari alat peraga yang telah dibuat. Melalui serangkaian metode pembelajaran berbasis aktivitas, kemampuan pemahaman dan analisis masalah psikologi faal mahasiswa meningkat.

\section{SIMPULAN DAN SARAN}

Pada penelitian ini ditarik kesimpulan sebagai berikut:

1. Metode pembelajaran berbasis aktivitas meningkatkan pemahaman matakuliah Psikologi Faal mahasiswa Fakultas Psikologi UIN SGD.

2. Metode pembelajaran berbasis aktivitas meningkatkan kemampuan analisis masalah yang berhubungan dengan perilaku pada matakuliah Psikologi Faal mahasiswa Fakultas Psikologi UIN SGD.

Berdasarkan analisis hasil penelitian, peneliti memberikan saran sebagai berikut: 1. Perlu dilakukan pengembangan penelitian berdasarkan metode pembelajaran berbasis aktivitas ini yang lebih memunculkan kreativitas mahasiswa.

2. Metode pembelajaran berbasis aktivitas ini dianjurkan untuk digunakan dalam metode pembelajaran mata kuliah lain pada fakultas psikologi.

\section{DAFTAR PUSTAKA}

Abrorachman. 1993. Psikologi pendidikan. Yogyakarta: Tiara wacana.

Ahmad,M dan Joko,S. 1997. Psikologi pendidikan. Jakarta: Pustaka setia.
Arsyad, A. 2002. Pendekatan pembelajaran. Jakarta:PT Raja Grafindo Persada.

Bahri, Dj S. 2000. Strategi Belajar Mengajar. Jakarta: Rineka Cipta.

Burton, 1986 Dalam Syamsuddin,A. 2001. Psikologi Pendidikan .Jakarta: Remaja Rosdakarya.

Cholil,U. 1995. Ikhtisar psikologi pendidikan, Surabaya: Duta Arkasa.

Costa, AL. 1985. The Principals'sRole in and Hancing Thingking Skills. Alxandria: ASCD.

Dahar, RW. 2010. Teori-Teori Belajar dan Pembelajaran. Jakarta: Erlangga.

Dalyono,M. 2009. Psikologi Pendidikan. Jakarta: Rineka Cipta.

Dierich, P.D., 1999. Dalam Solihin,L. 2001. Aktivitas Belajar Anak. Http://www.1.bpkpenabur.or.id

Dimyati dan Mudjiono. 2002. Belajar dan Pebelajaran,

Jakarta:Penerbit Kerjasama Pusat Perbukuan Depdiknas dan PT Rineka Cipta,

Hopkins, W. S. and Moore, K. D. 1991. Student teaching supervisor's handbook. School of Education and Behavioral Sciences, Cameron University: Lawton.

Isjoni. 2009. Cooperative Learning. Bandung: Alfabeta.

Joyce, B. Weil, M., \& Calhoun, E. 2000. Models of Teaching. London: Allyn and Bacon.

Kusmana,E. 1989. Analisis Terhadap Aspek-Aspek Kepemimpinan yang MempengaruhiTingkat Stabilitas dan Prestasi Akademik Perguruan Tingggi Swasta. Disertasi, Universitas Pendidikan Indonesia, Bandung.

Mudyaharjo,R. 1985. Dasar-Dasar Kependidikan. Bandung: IKIP

Muhibbin Syah. 2004. Psikologi Pendidikan dengan Pendekatan Baru. Bandung: PT Remaja Rosdakarya.

Mulyasa, E. 2003. Kurikulum Tingkat Satuan Pendidikan. Bandung: Remaja Rosida Karya 
Mulyono,A. 2003. Pendidikan bagi anak berkesulitan belajar. Rineka Cipta; Jakarta

Munandar, U. 2002. Kreativitas dan Keberbakatan: Strategi Mewujudkan Potensi Kreatif dan Baka. Jakarta: Gramedia.

Nurhadi, B. Yasin, A.G. Senduk (2004). Pembelajaran Kontekstual dan Penerapannya dalam KBK. Penerbit Universitas Negeri Malang: Malang.

Sardiman, AM. 2007. Interaksi dan Motivasi Belajar Mengajar. Jakarta: PT. Raja Grafindo Persada.

Sardiman,AS. 2003. Media Pendidikan. Jakarta: Rajawali Pers.

Sarwono,SW. 1978. Berkenalan dengan Aliran-Aliran dan Tokoh-tokoh Psikologi, Jakarta: Bulan Bintang.

Schunk, D. H. 2000. "Motivation for achievement: Past, present, and future". Issues in Education: Contributions from Educational Psychology, 6, 161-165.

Sudjana, N. 2000. Cara Belajar Siswa Aktif dalam Proses Belajar Mengajar. Bandung: Sinar Baru Algesindo.
Sudjana,N dan Rifai,A. 2002. Media Pengajaran. Cetakan ke-5. Bandung: Sinar Baru Algesindo.

Sudjana, N. 2010. Penilaian Hasil Proses Belajar Mengajar. Cetakan ke-15. Bandung: PT. Ramaja Rosdakarya.

Sudrajat,A. Teori-teori belajar. Didownload dari: ttp://muhammadsalahuddin.student. umm.ac.id/2010/01/29/teori-teoribelajar.

Sumiati dan Asra. 2008. Pendekatan pembelajaran. Bandung: Wacana Prima.

Suryabrata,S. 1998. Psikologi Pendidikan. Jakarta: PT Raja Grafindo Persada.

Tadjab, 1992. Ilmu jiwa pendidikan, Malang: Karya Abditama.

Wasty, S. 1998. Psikologi pendidikan, Jakarta : Rineka Cipta.

Winkel,WS. 2005.Psikologi Pengajaran, Yogyakarta:Penerbit Media Abadi.

Yusufhadi,M. 2004. Menyemai Benih Teknologi

Pendidikan, Jakarta:Penerbit Prenada Media. 